Coordination Chemistry

\title{
Stannylene or Metallastanna(IV)ocane: A Matter of Formalism**
}

\author{
Erica Brendler, Erik Wächtler, Thomas Heine, Lyuben Zhechkov, Thorsten Langer, \\ Rainer Pöttgen, Anthony F. Hill, and Jörg Wagler*
}

Dedicated to Professor Martin A. Bennett on the occasion of his 75th birthday

The $\sigma$ basicity of electron-rich transition metals $(\mathrm{TMs})^{[1]}$ plays a crucial role in Brønsted acid-base reactions of $\mathrm{TM}$ complexes, such as $\left[\mathrm{H}_{2} \mathrm{Fe}(\mathrm{CO})_{4}\right]$ and $\left[\mathrm{HCo}(\mathrm{CO})_{4}\right]$ (strong acids, poor $\sigma$-basicity of the corresponding conjugate bases) and was shown to increase upon coordination of good donor ligands L, such as phosphines; that is, lowered acidity of $\left[\mathrm{H}_{2} \mathrm{Fe}(\mathrm{CO})_{3}\left(\mathrm{PPh}_{3}\right)\right]$ or $\left[\mathrm{HCo}(\mathrm{CO})_{3}\left(\mathrm{PPh}_{3}\right)\right] .{ }^{[2]}$ Thus, $\mathrm{P}$ and/or $\mathrm{S}$ donors bearing electron-rich TM centers have been shown to support $\sigma$ donation towards other main-group-element (E) Lewis acidic centers, for example in the so-called metallaboratranes I and II and $\mathrm{Be}, \mathrm{Al}$, and $\mathrm{Ga}$ compounds of type III (Scheme 1). ${ }^{[3]}$ Very recently, we have described compounds IV-VII comprising $\left\{\mathrm{L}_{5} \mathrm{TM}\left(\mathrm{d}^{8}\right)\right\}$ moieties that exhibit $\sigma$ donation towards electronically saturated Lewis acidic centers $\mathrm{E}$, that is, $\mathrm{Si}^{\mathrm{IV}[4]}$ and $\mathrm{Sn}^{\mathrm{IV}} \cdot{ }^{[5]}$ Gabbaï et al. have reported similar intermetallic interactions in the heterobimetallic complexes VIII-X (Scheme 1), which comprise $\mathrm{d}^{10} \mathrm{TM}$ donor sites with an almost square-planar coordination sphere. ${ }^{[6]}$

Whereas compounds $\mathbf{I V}-\mathbf{X}$ were obtained by a straightforward route starting from sources that comprise TM and $\mathrm{E}$ in the desired oxidation states, herein we present a (formal) redox approach, which involves a reaction sequence starting

[*] E. Wächtler, Dr. J. Wagler

Institut für Anorganische Chemie

Technische Universität Bergakademie Freiberg

09596 Freiberg (Germany)

Fax: $(+49)$ 3731-39-4058

E-mail: joerg.wagler@chemie.tu-freiberg.de

Dr. E. Brendler

Institut für Analytische Chemie

Technische Universität Bergakademie Freiberg

09596 Freiberg (Germany)

Prof. Dr. T. Heine, Dr. L. Zhechkov

Center for Functional Nanomaterials (NanoFun)

School of Engineering and Science

Jacobs University Bremen (Germany)

Dipl.-Chem. T. Langer, Prof. Dr. R. Pöttgen

Institut für Anorganische und Analytische Chemie

Universität Münster (Germany)

Prof. Dr. A. F. Hill

Institute of Advanced Studies, Research School of Chemistry

The Australian National University, Canberra (Australia)

[***] J.W. acknowledges support by the German Academic Exchange Service (DAAD).

(2) Supporting information for this article is available on the WWW under http://dx.doi.org/10.1002/anie.201007967.
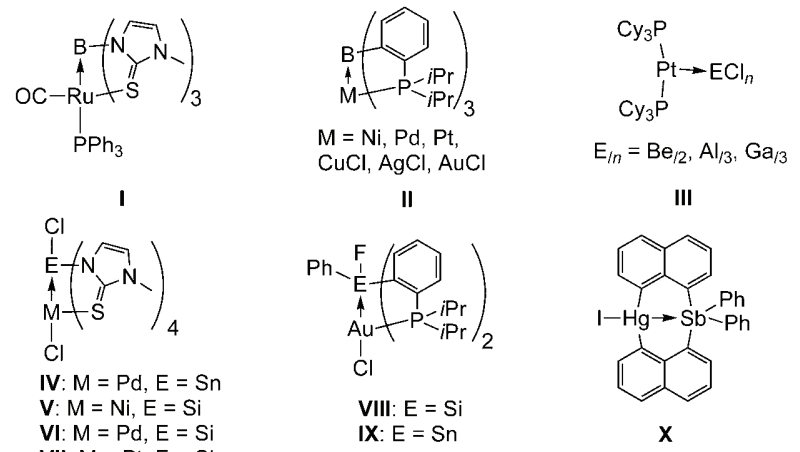

II

III
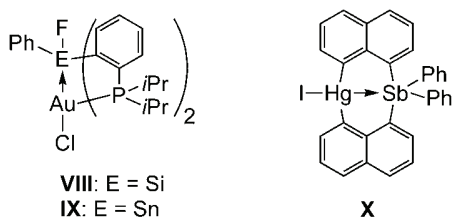

Scheme 1. Selected examples of TM-base complexes with electrophilic main-group-element sites ("Z-type ligands"). Cy=cyclohexyl.

from a stannylene $\left(\mathrm{SnCl}_{2}\right)$ and yielding hypercoordinate tin compounds that can be regarded as palladastanna(IV)ocanes.

In a convenient one-pot synthesis, $\left[\mathrm{PdCl}_{2}\left(\mathrm{PPh}_{3}\right)_{2}\right]$ was treated with the potassium salt of 1-methyl-2-mercaptoimidazole (methimazole, $\mathrm{Hmt}$ ) and $\left[\mathrm{SnCl}_{2}\right.$ (dioxane)] (Scheme 2) to afford compound $\mathbf{1}$. Substitution of the tin-bound chlorine atoms with a dianionic tridentate ligand ${ }^{[7]}$ afforded compound 2, which comprises a hexacoordinate tin atom (Scheme 2). Reference compounds $\mathbf{3}$ and $\mathbf{4}$ (comprising $\mathrm{Sn}^{\mathrm{IV}}$ and $\mathrm{Sn}^{\mathrm{II}}$, respectively, and the same tridentate ONN ligand as 2) were prepared as references for spectroscopic properties. The molecular structures of 1-4 were confirmed crystallographically (see Figure 1 and the Supporting Information). ${ }^{[8]}$

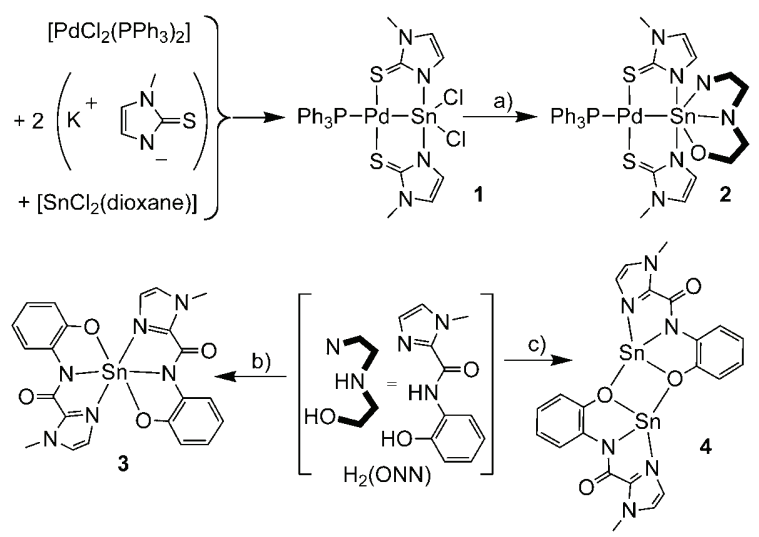

Scheme 2. Syntheses of compounds 1-4. a) $\mathrm{H}_{2}(\mathrm{ONN}),{ }^{[7]} \mathrm{Et}_{3} \mathrm{~N}, \mathrm{CH}_{2} \mathrm{Cl}_{2}$; b) $\left(\mathrm{NH}_{4}\right)_{2} \mathrm{SnCl}_{6}, \mathrm{Et}_{3} \mathrm{~N}, \mathrm{MeOH}$; c) $\left[\mathrm{SnCl}_{2}\right.$ (dioxane)], $\mathrm{Et}_{3} \mathrm{~N}, \mathrm{CHCl}_{3}$. 


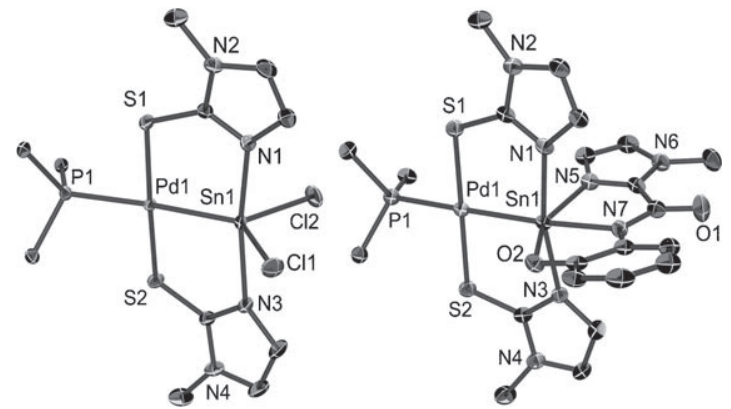

Figure 1. Molecular structures of $\mathbf{1}$ (left) and $\mathbf{2}$ (right) in the crystal ${ }^{[8]}$ with selected atom labels (ellipsoids set at $60 \%$ probability). For clarity, all hydrogen atoms are omitted and the P-bound phenyl groups were reduced to their ipso-C atoms. Selected bond lengths $[\AA]$ : 1: Pd1-Sn1 2.5382(1), Pd1-P1 2.3703(2), Pd1-S1 2.3123(2), Pd1-S2 2.3189(2), Sn1-Cl1 2.4006(2), Sn1-Cl2 2.3740(2), Sn1-N1 2.2098(6), Sn1-N3 2.2307(6); 2: Pd1-Sn1 2.5443(2), Pd1-P1 2.3792(6), Pd1-S1 2.3143(5), Pd1-S2 2.3207(5), Sn1-N1 2.218(2), Sn1-N3 2.240(2), Sn1-O2 2.089(1), Sn1-N5 2.266(2), Sn1-N7 2.172(2).

The coordination of the $\mathrm{SnCl}_{2}$ moiety to the $\mathrm{Pd}^{\mathrm{II}}$ center could at first sight be interpreted as involving a $\mathrm{Pd}^{\mathrm{II}}-\mathrm{Sn}^{\mathrm{II}}$ stannylene complex. The rather short distance between tin and the methimazole nitrogen atoms N1/N3 (shorter than both the axially and equatorially situated and formally dative $\mathrm{Sn}-\mathrm{N}$ bonds in stannylenes consisting of pentacoordinate tin bound to TMs of the general type $\mathrm{TM} \leftarrow \mathrm{Sn}(\mathrm{ON})_{2}$ and $\mathrm{TM} \leftarrow \mathrm{Sn}(\mathrm{ONNO})^{[9]}$ with 2 -aminoalcoholate, oxinate, and salen $\mathrm{O}, \mathrm{N}$-donor ligands) and also the propensity of tin to increase its coordination number up to six, however, resemble characteristics of $\mathrm{Sn}^{\mathrm{IV}}$. The dichotomy may be interpreted with recourse to the alternative descriptions depicted in Scheme 3 .

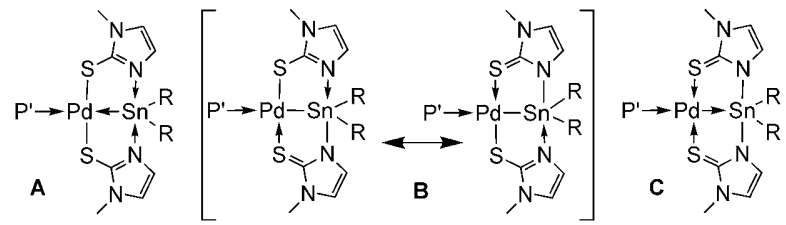

Scheme 3. Three alternative forms for the interpretation of compounds $\mathbf{1}$ and $\mathbf{2}$ as palladium stannylene $\left[\mathrm{Pd}^{\prime \prime} \leftarrow \mathrm{Sn}^{\prime \prime}\right](\mathbf{A})$, stannylpalladium $\left[\mathrm{Pd}^{\prime}-\mathrm{Sn}^{\prime \prime \prime}\right](\mathrm{B})$, and palladastanna(IV)ocane $\left[\mathrm{Pd}^{0} \rightarrow \mathrm{Sn}^{\mathrm{IV}}\right]$ systems (C). $\mathrm{P}^{\prime}=\mathrm{PPh}_{3}, \mathbf{1}: \mathrm{R}_{2}=\mathrm{Cl}_{2}, 2$ : ONN chelating ligand (see Scheme 2).

For compound VI, we have shown that the $\mathrm{Pd} \rightarrow \mathrm{Si}$ function in the coordination sphere of $\mathrm{Si}^{\mathrm{IV}}$ exerts a similar influence on the ${ }^{29} \mathrm{Si}$ NMR spectroscopy chemical shift as main-group donor atoms, such as $\mathrm{O}, \mathrm{N}$, or $\mathrm{Cl}$. Accordingly, the ${ }^{119}$ Sn NMR spectroscopic characteristics of $\mathbf{1}$ and $\mathbf{2}$ were investigated by ${ }^{119} \mathrm{Sn}$ solid-state magic-angle-spinning (MAS) NMR spectroscopy and supported by a computational analysis. The experimental spectra exhibit doublet signal splitting (ca. $4.5 \mathrm{kHz}$ ), in good agreement with the ${ }^{2} J\left(\mathrm{Sn}^{3}{ }^{3} \mathrm{P}\right)$ coupling observed in ${ }^{31} \mathrm{P}$ NMR spectra in solution $\left({ }^{2} J\left({ }^{117} \mathrm{Sn}-\right.\right.$ $\left.{ }^{31} \mathrm{P}\right),{ }^{2} J\left({ }^{119} \mathrm{Sn}^{31} \mathrm{P}\right)$ for 1: $4476 \mathrm{~Hz}, 4684 \mathrm{~Hz}$; 2: $4387 \mathrm{~Hz}$, $4591 \mathrm{~Hz}$ ), thus indicating pronounced internuclear electronic
$\mathrm{P}-\mathrm{Sn}$ interaction via $\mathrm{Pd}$ and providing evidence for the presence of a $\mathrm{Pd}-\mathrm{Sn}$ bond. Furthermore, the $\mathrm{Pd}-\mathrm{Sn}$ distances $(2.54 \AA)$ in $\mathbf{1}$ and $\mathbf{2}$ are significantly shorter than those typically observed in binary and ternary palladium stannides, for example, 2.77-2.80 $\AA$ in $\mathrm{CaPdSn}_{2}{ }^{[10 a]}$ and 2.78-2.84 $\AA$ in $\operatorname{PdSn}_{x}(x=2,3,4),{ }^{[10 b]}$ which is consistent with strong $\mathrm{Pd}-\mathrm{Sn}$ bonding in $\mathbf{1}$ and $\mathbf{2}$.

The ${ }^{119} \mathrm{Sn}$ chemical shifts $\delta_{\text {iso }}$ for $\mathbf{1}(-337 \mathrm{ppm})$ and $\mathbf{2}$ $(-557 \mathrm{ppm})$ are indeed characteristic of penta- and hexacoordinate $\mathrm{Sn}^{\mathrm{IV}}$ complexes, respectively (for example, those in Scheme 4). ${ }^{[11-14]}$ As stannylenes with tetracoordinate tin

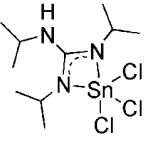

$-357$

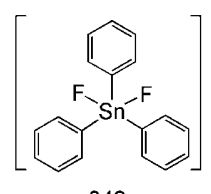

342

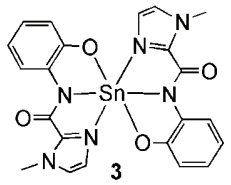

$-488$

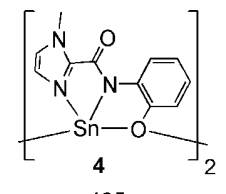

$-465$
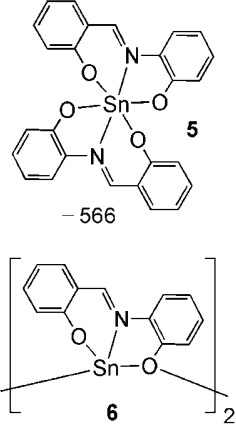

596
Scheme 4. Selected tin compounds with $\left\{\mathrm{Sn}^{\mathrm{IV}}\left(\mathrm{N}_{2} \mathrm{Cl} \mathrm{C}_{3}\right)\right\}^{\left[{ }^{[1]}\right.}\left\{\mathrm{Sn}^{\mathrm{IV}}\right.$ $\left.\left(\mathrm{N}_{4} \mathrm{O}_{2}\right)\right\},{ }^{[12]}\left\{\mathrm{Sn}^{1 \mathrm{~V}}\left(\mathrm{~N}_{2} \mathrm{O}_{4}\right)\right\},{ }^{[13]}\left\{\mathrm{Sn}^{1 \mathrm{~V}} \mathrm{Ph}_{3} \mathrm{~F}_{2}\right\},{ }^{[14]}\left\{\mathrm{Sn}^{11}\left(\mathrm{~N}_{2} \mathrm{O}_{2}\right)\right\},{ }^{[12]}$ and $\left\{\mathrm{Sn}^{11}-\right.$ $\left.\left(\mathrm{NO}_{3}\right)\right\}^{[13]}$ coordination spheres and associated ${ }^{119} \mathrm{Sn}$ NMR shifts $(\delta$ in ppm versus $\mathrm{SnMe}_{4}$ as standard).

(such as $\mathbf{4}$ and 6) may exhibit ${ }^{119} \mathrm{Sn}$ NMR shifts similar to those of related hexacoordinate $\mathrm{Sn}^{\mathrm{IV}}$ complexes (such as $\mathbf{3}$ and $\mathbf{5}$, respectively; Scheme 4), the chemical shift anisotropy (CSA) tensors of 1-4 were analyzed (see the Supporting Information for details). Noteworthy differences arise from the spin-orbit (SO) contributions to the ${ }^{119} \mathrm{Sn}$ shielding (Table 1). Whereas

Table 1: Principal components of the spin-orbit (SO) shielding contributions $\left(\sigma^{50}\right)$ to the ${ }^{119} \mathrm{Sn}$ CSA tensors of $\mathbf{1 - 4}$.

\begin{tabular}{lcccc}
\hline & 1 & 2 & 3 & 4 \\
\hline$\sigma^{\mathrm{SO}}{ }^{11}$ & 451 & 440 & 490 & 151 \\
$\sigma^{\mathrm{SO}}{ }^{22}$ & 578 & 568 & 495 & 228 \\
$\sigma^{\mathrm{SO}^{33}}$ & 675 & 635 & 514 & 514 \\
$\sigma^{\mathrm{SO}_{33}-\sigma^{\mathrm{SO}}{ }_{11}}$ & 224 & 195 & 24 & 363 \\
\hline
\end{tabular}

the octahedral tin coordination sphere of $\mathbf{3}$ is reflected by an almost cubic SO influence $\left(\sigma^{\mathrm{SO}}{ }_{11}, \sigma^{\mathrm{SO}}{ }_{22}, \sigma^{\mathrm{SO}}{ }_{33}\right.$ of similar magnitude), the stannylene lone pair of $\mathbf{4}$ may be responsible for the noticeably lower SO shielding effects $\left(\sigma^{\mathrm{SO}}{ }_{11}, \sigma^{\mathrm{SO}}{ }_{22}\right)$ perpendicular to the formal lone-pair direction. These lonepair characteristics disappear in $\mathbf{1}$ and $\mathbf{2}$. Although the span $\sigma^{\mathrm{SO}}{ }_{33}-\sigma^{\mathrm{SO}}{ }_{11}$ is larger for $\mathbf{1}$ and $\mathbf{2}$ than for the $\mathrm{Sn}^{\mathrm{IV}}$ complex $\mathbf{3}$, the principal components $\sigma^{\mathrm{SO}}{ }_{11}, \sigma^{\mathrm{SO}}{ }_{22}$, and $\sigma^{\mathrm{SO}}{ }_{33}$ show little influence from the tin coordination sphere (trigonal bipyramidal versus octahedral) and the direction $\sigma^{\mathrm{SO}}{ }_{33}$ deviates from the direction of the supposed lone pair ( $\mathrm{Sn}-\mathrm{Pd}$ axis), in particular in compound $\mathbf{2}$. 
Further evidence in favor of contributions of the palladastanna(IV)ocane $\left[\mathrm{Pd}^{0} \rightarrow \mathrm{Sn}^{\mathrm{IV}}\right]$ form $\mathbf{C}$ to the bonding situation in $\mathbf{1}$ and $\mathbf{2}$ is provided by a natural bonding orbital (NBO) analysis, from which the natural charges (NC) were derived. Whereas similar NCs would be expected for palladium and tin for the oxidation states + II for both atoms, contributions of form $\mathbf{C}$ should indicate that palladium has a notably lower charge than tin. The NCs obtained for $\mathbf{1}$ and $\mathbf{2}$ (Table 2) hint at similarities of the $\mathrm{Pd}-\mathrm{Sn}$ bonding situation in

Table 2: Selected NCs and orbital occupancies obtained from NBO analyses.

\begin{tabular}{llllll}
\hline & $\mathrm{NC}(\mathrm{Pd})$ & $\mathrm{NC}(\mathrm{Sn})$ & $\mathrm{NC}(\mathrm{X})$ & $5 \mathrm{~s}(\mathrm{Sn})$ & $5 \mathrm{p}(\mathrm{Sn})$ \\
\hline $\mathbf{1}$ & -0.54 & 1.77 & $-0.55^{[\mathrm{a}]}$ & 1.00 & 1.20 \\
$\mathbf{1}-\mathrm{F}_{2}$ & -0.58 & 2.24 & $-0.74^{[\mathrm{a}]}$ & 0.89 & 0.87 \\
$\mathbf{1}-\mathrm{Me}_{2}$ & -0.50 & 1.77 & $-0.46^{[a]}$ & 0.97 & 1.25 \\
$\mathbf{1}-\mathrm{H}_{2}$ & -0.47 & 1.23 & $-0.25^{[a]}$ & 1.10 & 1.67 \\
$\mathbf{2}$ & -0.55 & 2.16 & & 0.83 & 0.99 \\
$\mathbf{3}$ & & 2.55 & & 0.57 & 0.87 \\
$\mathbf{4}$ & & 1.44 & & 1.72 & 0.84 \\
$\mathbf{7}^{+}$ & -0.54 & 1.70 & & 1.10 & 1.16 \\
$\mathbf{8}$ & -0.51 & 1.72 & & 1.06 & 1.17 \\
\hline
\end{tabular}

[a] Average value of the two almost identical NCs.

both compounds. The most obvious change upon transformation of $\mathbf{1}$ into $\mathbf{2}$ is the increase of the tin NC by +0.39 . This effect can be attributed to reduced charge compensation in the more ionic $\mathrm{Sn}-\mathrm{O}$ and $-\mathrm{N}$ bonds relative to $\mathrm{Sn}-\mathrm{Cl}$. This is underlined by corresponding NCs of computed model compounds $\mathbf{1}-\mathrm{F}_{2}, \mathbf{1}-\mathrm{Me}_{2}$, and $\mathbf{1}-\mathrm{H}_{2}$ (Scheme 5, Table 2).

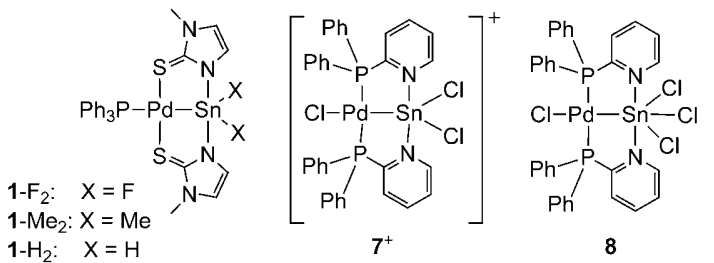

Scheme 5. Further Pd-Sn complexes considered in our NBO analysis.

Regardless of this difference between $\mathbf{1}$ and $\mathbf{2}$, the $\mathrm{NC}$ at tin in $2(+2.16)$ corresponds very well with the $\mathrm{NC}$ of tin in complex 3 and NCs computed for other hypercoordinate $\mathrm{Sn}^{\mathrm{IV}}$ compounds. For example, a value of about +2.5 was obtained for pentacoordinate $\mathrm{Sn}^{\text {IV }}$ centers in tin-oxo clusters, ${ }^{[15]}$ whereas for stannylene 4 the $\mathrm{NC}$ was calculated to be +1.44 , and also for $\mathrm{Sn}^{\mathrm{II}}$ bis(amidinate)s $\left(\left\{\mathrm{Sn}^{\mathrm{II}} \mathrm{N}_{4}\right\}\right.$ skeleton), tin NCs of less than +1.5 were derived. ${ }^{[16]}$ Furthermore, the $5 \mathrm{~s}$ occupancies within the calculated natural valence shell populations of the tin atoms of $\mathbf{1}$ and $\mathbf{2}$ (1.00 and 0.83 , respectively) are intermediate between those of $\mathrm{Sn}^{\mathrm{IV}}$ compounds $\left(30.57, \mathbf{I V} 0.68^{[5]}\right)$ and a recently reported $\mathrm{Sn}^{\mathrm{III}}$ compound (1.16). ${ }^{[17]}$ The variation in the NCs located at tin in compounds $\mathbf{1}, \mathbf{2}, \mathbf{1}-\mathrm{F}_{2}, \mathbf{1}-\mathrm{Me}_{2}$, and $\mathbf{1}-\mathrm{H}_{2}$ is thus dominated by variable $5 \mathrm{p}$ occupancy arising from covalent versus ionic contributions to $\mathrm{Sn}-\mathrm{X}$ bonds to additional substituents. The preceding data are clearly supportive of the interpretation as $\mathrm{Pd}^{\mathrm{I}}-\mathrm{Sn}^{\mathrm{III}}$ or $\mathrm{Pd}^{0} \rightarrow \mathrm{Sn}^{\mathrm{IV}}$ systems (form $\mathbf{B}$ or $\mathbf{C}$, respectively) rather than the stannylene model $\mathrm{Pd}^{\mathrm{II}} \leftarrow \mathrm{Sn}^{\mathrm{II}} \mathbf{A}$. Recently, Deelman et al. presented complexes $\mathbf{7}^{+}$and $\mathbf{8}$ with similar $\mathrm{Pd}-$ Sn coordination spheres (Scheme 5).$^{[18]}$ Our NBO analysis of the optimized gas-phase structures of $\mathbf{7}^{+}$and $\mathbf{8}$ confirmed that their electronic features are very similar to those of compound 1 (Table 2).

These NCs calculations of compounds $\mathbf{1 - 4}$ are in excellent agreement with the ${ }^{119} \mathrm{Sn}$ Mössbauer spectroscopic data (Table 3). ${ }^{[19]}$ As the tin NC increases in the order $\mathbf{4}<\mathbf{1}<\mathbf{2}<$

Table 3: Fitting parameters for ${ }^{119} \mathrm{Sn}$ Mössbauer spectroscopic measurements on $1-4$ at $78 \mathrm{~K} \cdot{ }^{[a]}$

\begin{tabular}{llll}
\hline Compound & $\delta\left[\mathrm{mm} \mathrm{s}^{-1}\right]$ & $\Delta E_{\mathrm{Q}}\left[\mathrm{mm} \mathrm{s}^{-1}\right]$ & $\Gamma\left[\mathrm{mm} \mathrm{s}^{-1}\right]$ \\
\hline $\mathbf{1}$ & $1.48(1)$ & $1.59(1)$ & $0.82(2)$ \\
$\mathbf{2}$ & $1.14(1)$ & $1.93(1)$ & $0.84(1)$ \\
$\mathbf{3}$ & $0.26(1)$ & $0.94(1)$ & $0.94(2)$ \\
$\mathbf{4}$ & $3.09(1)$ & $1.85(1)$ & $0.85(2)$ \\
\hline
\end{tabular}

[a] $\delta=$ Isomer shift, $\Delta E_{Q}=$ electric quadrupole interaction, $\Gamma=$ experimental line width.

3, we observe a lower isomer shift in the same order. Whereas the mixed-valent complexes $\left[\left\{\left(\mathrm{RSn}^{\mathrm{IV}}\right)_{2}(\mu-\mathrm{S})_{2}\right\}_{3} \mathrm{Sn}_{2}{ }_{2}^{\mathrm{III}} \mathrm{S}_{6}\right]^{[20]}$ $\left(\mathrm{R}=\mathrm{CMe}_{2} \mathrm{CH}_{2} \mathrm{COMe}\right)$ and $\left[\mathrm{ClSi}(\mu-\mathrm{mt})_{4} \mathrm{SnCl}\right] \cdot 3$ (dioxane) $(\mathrm{mt}=\text { methimazolyl })^{[17]}$ have isomer shifts of $2.0 \mathrm{~mm} \mathrm{~s}^{-1}$ (characteristic of trivalent tin), the signals of $\mathbf{4}$ and $\mathbf{3}$ are characteristic of $\mathrm{Sn}^{\mathrm{II}}$ and $\mathrm{Sn}^{\mathrm{IV}}$ compounds, respectively. The isomer shifts of compounds $\mathbf{1 - 4}$ correspond very well to their computed 5s occupancies (linear correlation with $R^{2}=0.99$ ). They also fit the systematic shift for various other tin compounds well. ${ }^{[13,21]}$ In sharp contrast to the shift of stannylene 4, compounds $\mathbf{1}$ and $\mathbf{2}$ show isomer shifts in the characteristic range for $\mathrm{Sn}^{\mathrm{III}}$ and $\mathrm{Sn}^{\mathrm{IV}}$ (in support of forms $\mathbf{B}$ and $\mathbf{C}$ ).

A stannylene, when coordinated to an electron-rich lateTM center, may display characteristics that are consistent with a $\mathrm{Sn}^{\text {IV }}$ compound, thus raising questions regarding the adequacy of the TM-stannylene complex model for interpreting the bonding in complexes that arise from a TM and a stannylene. X-ray diffraction analyses, ${ }^{119}$ Sn NMR spectroscopy, and NBO analyses are in accord with the interpretation of the $\mathrm{Pd}-\mathrm{Sn}$ bonding in compounds $\mathbf{1}$ and $\mathbf{2}$ as being intermediate between stannyl(III)-palladium(I) complexes (B) and palladastanna(IV)ocanes (C), thus assigning a lowered formal oxidation state to palladium and an enhanced oxidation state to tin, and thereby indicating an intramolecular redox process upon stannylene complex formation. This interpretation is reinforced by ${ }^{119} \mathrm{Sn}$ Mössbauer spectroscopic data.

To date, only a limited number of TM-Sn complexes are known that comprise a $\left\{\mathrm{TM}-\mathrm{SnE}_{5}\right\}(\mathrm{E}=$ main-group element $)$ hexacoordinate tin center, which is characteristic for $\mathrm{Sn}^{\mathrm{IV}}$. Most of those complexes involve the tin atom as part of an $\mathrm{SnB}_{11} \mathrm{H}_{11}$ cage, that is, attached to electropositive substituents, in a situation for which simple integral valence models are less useful; ${ }^{[22]}$ an electron-rich tin center $(\mathrm{NC}(\mathrm{Sn})+0.94$ in 
$\mathrm{H}_{11} \mathrm{~B}_{11} \mathrm{Sn}^{2-}$ ) is thus evisaged for this particular coordination environment. ${ }^{[23]}$ Further examples are found with compounds comprising a $\left\{\mathrm{TM}-\mathrm{SnE}_{5}\right\}$ pattern, with $\mathrm{TM}$ being a Group 6 element. ${ }^{[24]}$ According to the isolobal concept, these TM centers appear less likely to act as lone-pair donors rather than being acceptors for a stannylene or stannyl lone pair. Although only a very limited number of examples for $\{\mathrm{TM}-$ $\left.\mathrm{SnE}_{5}\right\}$ and $\left\{\mathrm{TM}-\mathrm{SnE}_{4}\right\}$ complexes were reported for electronrich TM centers, ${ }^{[5,6,18]}$ the comparison of $\mathbf{1}$ and $\mathbf{2}$ has shown that even in complexes of the general type $\left\{\mathrm{TM}-\mathrm{SnE}_{4}\right\}$ (with pentacoordinate tin), the interpretation as a metallastanna(IV)ocane-like compound might be appropriate. Thus, it should be pointed out that other presumed stannylene complexes of late TMs comprising a pentacoordinate tin atom $^{[25]}$ might exhibit similar features (that is, tin in an oxidation state of more than + II). As to seemingly simple stannylene complexes, even compounds such as $\left[\mathrm{Cl}_{2} \mathrm{Sn}=\right.$ $\left.\mathrm{Fe}(\mathrm{CO})_{4}\right]^{[26]}$ (or derivatives thereof) might thus reveal significant contributions of a $\left[\mathrm{Cl}_{2} \mathrm{Sn}^{\mathrm{IV}}\right]^{2+} \leftarrow\left[\mathrm{Fe}^{-\mathrm{II}}(\mathrm{CO})_{4}\right]^{2-}$ form in addition to the widely accepted interpretation as a $\left[\mathrm{Cl}_{2} \mathrm{Sn}^{\mathrm{II}}\right] \rightarrow$ $\left[\mathrm{Fe}^{0}(\mathrm{CO})_{4}\right]$ stannylene complex, the former being also supported by the easy accessibility and stability of the dianion $\left[\mathrm{Fe}^{-\mathrm{II}}(\mathrm{CO})_{4}\right]^{2-}$. The extension of this work to the applicability of the ylene ligand model would include various ligands with metalloid donor atoms, such as the related germylenes and silylenes, and also alumylene, gallylene, arsine, and stibine ligand systems, the lone-pair donor sites of which have the potential of exhibiting a higher oxidation state $(\mathrm{Al}, \mathrm{Ga}$ : + III instead of $+\mathrm{I}$; As, Sb: $+\mathrm{V}$ instead of $+\mathrm{III})$, thus reverting the formal roles of $\sigma$-donor and $\sigma$-acceptor.

\section{Experimental Section}

1: A freshly prepared solution of potassium methimazolide, prepared by addition of a $\mathrm{KN}\left(\mathrm{SiMe}_{3}\right)_{2}$ solution in toluene $(0.5 \mathrm{M}, 4 \mathrm{~mL})$ to a solution of methimazole $(0.23 \mathrm{~g}, 2.0 \mathrm{mmol})$ in THF $(5 \mathrm{~mL})$, was added to a suspension of $\left[\mathrm{PdCl}_{2}\left(\mathrm{PPh}_{3}\right)_{2}\right](0.70 \mathrm{~g}, 1.0 \mathrm{mmol})$ in THF $(5 \mathrm{~mL})$, whereupon an orange-red solution was obtained. Upon gentle heating, an orange precipitate formed. Solid $\left[\mathrm{SnCl}_{2} \text { (dioxane) }\right]^{[27]}$ $(0.28 \mathrm{~g}, 1.0 \mathrm{mmol})$ was then added and the mixture was stirred to give a clear red solution from which a pink precipitate separated within five minutes. The solid thus obtained was filtered off, washed with THF $(5 \mathrm{~mL})$, and extracted with dichloromethane. Removal of the solvent afforded red crystals of $\mathbf{1}(0.66 \mathrm{~g}, 0.84 \mathrm{mmol}, 84 \%)$. Elemental analysis (\%) calcd for $\mathrm{C}_{26} \mathrm{H}_{25} \mathrm{Cl}_{2} \mathrm{~N}_{4} \mathrm{PPdS}_{2} \mathrm{Sn}$ $\left(784.58 \mathrm{~g} \mathrm{~mol}^{-1}\right)$ : C 39.80, H 3.21, N 7.14; found: C 39.71, H 3.30, N 7.14. 2: Ligand $\mathrm{H}_{2} \mathrm{ONN}(0.07 \mathrm{~g}, 0.32 \mathrm{mmol})$ and $\mathbf{1}(0.25 \mathrm{~g}$, $0.32 \mathrm{mmol})$ were stirred in dichloromethane $(10 \mathrm{~mL})$, and triethylamine (ca. $0.1 \mathrm{~g}, 0.99 \mathrm{mmol}$ ) was added, whereupon the red crystals of 1 dissolved and a yellow solution formed. Upon addition of ethanol $(15 \mathrm{~mL})$, yellow crystals of 2 formed, which, upon evaporation of some dichloromethane (ca. $5 \mathrm{~mL}$ ), were separated by decantation, washed with ethanol $(5 \mathrm{~mL})$, and dried in air. Yield: $0.28 \mathrm{~g}$, $0.30 \mathrm{mmol}$, $94 \%$. Elemental analysis (\%) calcd for $\mathrm{C}_{37} \mathrm{H}_{34} \mathrm{~N}_{7} \mathrm{O}_{2} \mathrm{PPdS}_{2} \mathrm{Sn} \quad\left(928.89 \mathrm{~g} \mathrm{~mol}^{-1}\right): \quad \mathrm{C} 47.84, \quad \mathrm{H} 3.69, \quad \mathrm{~N} 10.56$; found: C 47.47, H 3.92, N 10.19. Compounds 1 and 2 decompose upon heating without melting. For ${ }^{1} \mathrm{H},{ }^{13} \mathrm{C},{ }^{31} \mathrm{P}$, and ${ }^{119} \mathrm{Sn} \mathrm{NMR}$ spectroscopic data and details of computational analyses, see the Supporting Information.

Received: December 16, 2010

Published online: April 14, 2011
Keywords: coordination chemistry · hypercoordination . palladium $\cdot$ tin $\cdot$ transition-metal basicity

[1] H. Werner, Angew. Chem. 1983, 95, 932-954; Angew. Chem. Int. Ed. Engl. 1983, 22, 927-949.

[2] a) R. Sowa, Jr., V. Zanotti, G. Facchin, R. J. Angelici, J. Am. Chem. Soc. 1991, 113, 9185-9192; b) D. F. Shriver, Acc. Chem. Res. 1970, 3, 231-238.

[3] a) A. F. Hill, G. R. Owen, A. J. P. White, D. J. Williams, Angew. Chem. 1999, 111, 2920-2923; Angew. Chem. Int. Ed. 1999, 38, 2759-2761; b) I. R. Crossley, A. F. Hill, A. C. Willis, Organometallics 2010, 29, 326-336, and references therein; c) M. Sircoglou, M. Mercy, N. Saffon, Y. Coppel, G. Bouhadir, L. Maron, D. Bourissou, Angew. Chem. 2009, 121, 3506-3509; Angew. Chem. Int. Ed. 2009, 48, 3454-3457; d) S. Bontemps, G. Bouhadir, W. Gu, M. Mercy, C.-H. Chen, B. M. Foxman, L. Maron, O. V. Ozerov, D. Bourissou, Angew. Chem. 2008, 120, 1503-1506; Angew. Chem. Int. Ed. 2008, 47, 1481-1484; e) M. Sircoglou, G. Bouhadir, N. Saffon, K. Miqueu, D. Bourissou, Organometallics 2008, 27, 1675-1678; f) J. Bauer, H. Braunschweig, P. Brenner, K. Kraft, K. Radacki, K. Schwab, Chem. Eur. J. 2010, 16, 11985-11992; g) H. Braunschweig, K. Gruss, K. Radacki, Angew. Chem. 2009, 121, 4303-4305; Angew. Chem. Int. Ed. 2009, 48, 4239-4241; h) H. Braunschweig, K. Gruss, K. Radacki, Angew. Chem. 2007, 119, 7929-7931; Angew. Chem. Int. Ed. 2007, 46, 7782-7784; i) H. Braunschweig, K. Gruss, K. Radacki, Inorg. Chem. 2008, 47, 8595-8597; j) G. Bouhadir, A. Amgoune, D. Bourissou, Adv. Organomet. Chem. 2010, 58, $1-$ 107.

[4] a) J. Wagler, E. Brendler, Angew. Chem. 2010, 122, 634-637; Angew. Chem. Int. Ed. 2010, 49, 624-627; b) L. A. Truflandier, E. Brendler, J. Wagler, J. Autschbach, Angew. Chem. 2011, 123, 269-273; Angew. Chem. Int. Ed. 2011, 50, 255-259.

[5] J. Wagler, A. F. Hill, T. Heine, Eur. J. Inorg. Chem. 2008, $4225-$ 4229.

[6] a) P. Gualco, T.-P. Lin, M. Sircoglou, M. Mercy, S. Ladeira, G. Bouhadir, L. M. Pérez, A. Amgoune, L. Maron, F. P. Gabbaï, D. Bourissou, Angew. Chem. 2009, 121, 10076-10079; Angew. Chem. Int. Ed. 2009, 48, 9892-9895; b) T.-P. Lin, C. R. Wade, L. M. Pérez, F. P. Gabbaï, Angew. Chem. 2010, 122, 6501-6504; Angew. Chem. Int. Ed. 2010, 49, 6357-6360; c) P. Gualco, M. Mercy, S. Ladeira, Y. Coppel, L. Maron, A. Amgoune, D. Bourissou, Chem. Eur. J. 2010, 16, 10808-10817.

[7] J. Wagler, A. F. Hill, Organometallics 2008, 27, 6579-6586.

[8] CCDC 798517 (1), 798518 (2), 798516 (3), and 798515 $\left(4 \cdot 2 \mathrm{CHCl}_{3}\right)$ ) contain the supplementary crystallographic data for this paper. These data can be obtained free of charge from The Cambridge Crystallographic Data Centre via www.ccdc. cam.ac.uk/data_request/cif. Space group, cell parameters, and $R$ values with $[I>2 \sigma(I)]: \mathbf{1}: P \overline{1}, a=8.8002(2), b=11.7182(2), c=$ 15.9093(3) $\AA, \alpha=105.695(1), \quad \beta=94.980(1), \quad \gamma=108.940(1)^{\circ}$, $R_{1}=0.0197, \quad w R_{2}=0.0484 . \quad 2: \quad P b c a, \quad a=17.7179(4), \quad b=$ 16.0002(3), $c=25.8367(6) \AA, R_{1}=0.0289, w R_{2}=0.0590 .3: P \overline{1}$, $a=7.5602(3), b=11.6779(6), c=12.3307(7) \AA, \alpha=81.511(2)$, $\beta=89.378(2), \quad \gamma=77.907(2)^{\circ}, \quad R_{1}=0.0397, \quad w R_{2}=0.0662$. 4. $\left(\mathrm{CHCl}_{3}\right)_{2}: \quad P 2_{1} / c, \quad a=8.5042(2), \quad b=11.1156(3), \quad c=$ 15.8801(3) $\AA, \beta=91.616(1)^{\circ}, R_{1}=0.0244, w R_{2}=0.0367$.

[9] a) V. N. Khrustalev, I. A. Portnyagin, M. S. Nechaev, S. S. Bukalov, L. A. Leites, Dalton Trans. 2007, 3489-3492; b) D. Agustin, G. Rima, H. Gornitzka, J. Barrau, Inorg. Chem. 2000, $39,5492-5495$; c) D. Agustin, G. Rima, H. Gornitzka, J. Barrau, Eur. J. Inorg. Chem. 2000, 693-702; d) P. Kircher, G. Huttner, B. Schiemenz, K. Heinze, L. Zsolnai, O. Walter, A. Jacobi, A. Driess, Chem. Ber. 1997, 130, 687-699.

[10] a) R.-D. Hoffmann, D. Kußmann, U. C. Rodewald, R. Pöttgen, C. Rosenhahn, B. D. Mosel, Z. Naturforsch. B 1999, 54, 709- 


\section{Communications}

717; b) J. Nylén, F. J. Garcìa Garcìa, B. D. Mosel, R. Pöttgen, U. Häussermann, Solid State Sci. 2004, 6, 147-155.

[11] S. R. Foley, G. P. A. Yap, D. S. Richeson, Polyhedron 2002, 21, $619-627$.

[12] For the syntheses of compounds $\mathbf{3}$ and $\mathbf{4}$, please refer to the Supporting Information.

[13] A. M. van den Bergen, J. D. Cashion, G. D. Fallon, B. O. West, Aust. J. Chem. 1990, 43, 1559-1571.

[14] J. Beckmann, D. Dakternieks, A. Duthie, E. R. T. Tiekink, J. Organomet. Chem. 2002, 648, 204-208.

[15] J. Beckmann, D. Dakternieks, A. Duthie, K. Jurkschat, M. Mehring, C. Mitchell, M. Schürmann, Eur. J. Inorg. Chem. 2003, $4356-4360$.

[16] a) W. W. Schoeller, A. Sundermann, M. Reiher, Inorg. Chem. 1999, 38, 29-37; b) W. W. Schoeller, A. Sundermann, M. Reiher, A. Rozhenko, Eur. J. Inorg. Chem. 1999, 1155-1159.

[17] J. Wagler, E. Brendler, T. Langer, R. Pöttgen, T. Heine, L. Zhechkov, Chem. Eur. J. 2010, 16, 13429-13434.

[18] a) Y. Cabon, H. Kleijn, M. A. Siegler, A. L. Spek, R. J. M. Klein Gebbink, B.-J. Deelman, Dalton Trans. 2010, 39, $2423-$ 2427; b) Y. Cabon, I. Reboule, M. Lutz, R. J. M. Klein Gebbink, B.-J. Deelman, Organometallics 2010, 29, 5904-5911.

[19] $\mathrm{A} \mathrm{Ca}^{119 \mathrm{~m}} \mathrm{SnO}_{3}$ source was available for the ${ }^{119} \mathrm{Sn}$ Mössbauer spectroscopic investigation at $78 \mathrm{~K}$. Fitting of the spectra was performed with the NORMOS-90 program system: R. A. Brand, Normos Mössbauer Fitting Program (Universität Duisburg) 2002.

[20] Z. Hassanzadeh Fard, C. Müller, T. Harmening, R. Pöttgen, S. Dehnen, Angew. Chem. 2009, 121, 4507-4511; Angew. Chem. Int. Ed. 2009, 48, 4441-4444.

[21] P. E. Lippens, Phys. Rev. B 1999, 60, 4576-4586.

[22] a) M. Kirchmann, K. Eichele, F. M. Schappacher, R. Pöttgen, L. Wesemann, Angew. Chem. 2008, 120, 977-980; Angew. Chem. Int. Ed. 2008, 47, 963 -966; b) M. Kirchmann, S. Fleischhauer, L. Wesemann, Organometallics 2008, 27, 2803-2808.

[23] T. Gädt, L. Wesemann, Z. Anorg. Allg. Chem. 2007, 633, 693 699.

[24] L.-F. Tang, X.-M. Zhao, Z.-H. Zou, H.-B. Song, Y.-P. Zhai, J. Organomet. Chem. 2005, 690, 4124-4131.

[25] a) J. Martincová, R. Jambor, M. Schürmann, K. Jurkschat, J. Honzíček, F. A. Almeida Paz, Organometallics 2009, 28, 4778 4782; b) M. L. Buil, M. A. Esteruelas, F. J. Lahoz, E. Oñate, L. A. Oro, J. Am. Chem. Soc. 1995, 117, 3619-3620.

[26] A. B. Cornwell, P. G. Harrison, J. Chem. Soc. Dalton Trans. 1975, 2017-2022.

[27] J. S. Morrison, H. M. Haendler, J. Inorg. Nucl. Chem. 1967, 29, $393-400$ 